\title{
PERLINDUNGAN HUKUMBAGI PENGGUNA KLINIK KECANTIKAN ESTETIKA BERDASARKAN PERSPEKTIF HAK KONSTITUSIONAL WARGA NEGARA
}

\author{
Siska Diana Sari \\ Universitas PGRI Madiun \\ Email : siskadianasari@ymail.com
}

Naskah diterima: 11/10/2018 revisi: 31/10/2018 disetujui: 31/10/2018

\begin{abstract}
Abstrak
Bisnis klinik kecantikan berkembang pesat, namun penyelenggaraannya harus disertai pemenuhan hak dan kewajiban bagi stakeholder yang terkait. Artikel ini bertujuan untuk membahas perlindungan hukum bagi pengguna klinik kecantikan estetika dalam perspektif hak konstitusional warga negara. Kajian dilakukan dengan metode kualitatif normatif pada peraturan perundang-undangan dan referensi tentang klinik kecantikan estetika di Indonesia. Hasil penelitian menunjukkan bahwa perlindungan hak konstitusional warga negara pada pelayanan di klinik kecantikan estetika di Indonesia meliputi hak jaminan perlindungan dan kepastian hukum sesuai dengan Undang Undang Dasar 1945 Pasal 28D ayat 1 yaitu dan 28H ayat 1 terkait hak kesehatan serta berhak memperoleh pelayanan kesehatan. Tanggung jawabnya terdapat pada pemerintah, pemenuhannya dengan Instrumen hukum dan lembaga negara yang berwenang pada tahapan perijianan, penyelenggaraan, pembinaan, pengawasan, monitoring dan evaluasi dalam penyelenggaraan klinik kecantikan estetika. Sedangkan klinik kecantikan estetika berkewajiban memenuhi perlindungan hukum terhadap kesalahan, resiko, produk dan profesional.
\end{abstract}

Kata kunci: Perlindungan Hukum, Klinik kecantikan estetika, Hak Konstitusional

\section{LEGAL PROTECTION FOR USERS OF AESTHETIC BEAUTY CLINICS IN THE PERSPECTIVE OF CONSTITUTIONAL RIGHTS OF CITIZENS}

\begin{abstract}
Beauty clinic business is thriving, but its must be accompanied by the fulfilment of rights and responsibilities for stakeholders. This article is legal protection for users of aesthetic beauty clinics in the perspective of constitutional rights of citizens. The study was done by the method of normative qualitative on legislation and reference of aesthetic beauty clinics in Indonesia. The results showed that the protection of the constitutional rights of citizens on service at the clinic, aesthetic beauty in Indonesia covering rights guarantee protection and legal certainty in accordance with the 1945 Constitution Article 28D paragraph 1 IE and 28 h paragraph 1 of the associated rights health as well as eligible medical services. There are responsibilities on the Government, its fulfillment with the instruments of law and State institutions authorized in stages perijianan, organizing, coaching, supervision, monitoring and evaluation in aesthetic beauty clinics. While aesthetic beauty clinics shall be obliged to meet legal protection against errors, risks, products and professionals.
\end{abstract}

Keywords: legal protection, Aesthetic Beauty Clinics, constitutional rights 



\section{PENDAHULUAN}

Indonesia merupakan negara hukum, hal ini tercantum jelas dalam Perubahan Keempat UUD 1945 pada tahun 2002, konsepsi Negara Hukum atau "Rechtsstaat" yang sebelumnya hanya tercantum dalam Penjelasan UUD 1945, dirumuskan dengan tegas dalam Pasal 1 ayat (3) yang menyatakan, "Negara Indonesia adalah Negara Hukum" (Jimly Asshiddiqqie, 2006:1-127). Berdasarkan konsep Negara Hukum itu, idealnya bahwa yang harus dijadikan panglima dalam dinamika kehidupan kenegaraan adalah hukum, bukan politik ataupun ekonomi.

Selain menegaskan tentang negara hukum, substansi Undang-Undang Dasar Negara Republik Indonesia Tahun 1945 berisi tentang hak dan kewajiban Warga Negara, di antara hak konstitusional yang dijamin adalah hak mendapatkan perlindungan hukum, hak kesehatan serta berhak memperoleh pelayanan kesehatan. Berkaitan dengah tiga hak tersebut maka terdapat amanat dalam konstitusi Undangundang Dasar Negara Republik Indonesia Tahun 1945, yaitu :

1. Pasal 28D ayat (1) yang berbunyi "Setiap orang berhak atas pengakuan, jaminan perlindungan, dan kepastian hukum yang adil serta perlakuan yang sama dihadapan hukum". Maksud dari ayat di atas adalah setiap warga negara berhak mendapat pengakuan dan perlindungan dari negara. Serta setiap warga negara berhak untuk mendapat perlakuan dihadapan hukum yang adil dan sama untuk semua warga negara tanpa ada perbedaan sedikitpun.

2. Pasal $28 \mathrm{H}$ ayat (1), yaitu : "Setiap orang berhak hidup sejahtera lahir dan batin, bertempat tinggal, dan mendapatkan lingkungan hidup yang baik dan sehat serta berhak memperoleh pelayanan kesehatan".

Terkait dengan perlindungan hukum, pelaksanaan dan penegakannya ada hak konstitusional warga negara yang harus dipenuhi oleh negara yaitu hak jaminan perlindungan dan kepastian hukum dan hak kesehatan serta berhak memperoleh pelayanan kesehatan. Pemenuhan hak tersebut tidak bisa dilepaskan dari dinamika perkembangan jaman, yaitu globalisasi yang merupakan salah satu hal yang tidak dapat dihindari oleh berbagai bangsa/negara di dunia, termasuk Indonesia. Segala yang terjadi di jaman globalisasi mempengaruhi pemenuhan hak tersebut, semakin banyak perkembangan maka semakin banyak juga tuntutan akan pemenuhan hak. Sebenarnya, globalisasi bukanlah sesuatu yang baru, semangat pencerahan eropa di abad pertengahan yang mendorong pencarian dunia baru dapat dikategorikan sebagai arus globalisasi. Salah satu penyebab perubahan sosial dan perubahan hukum adalah globalisasi.

Pembangunan negara-negara di dunia termasuk di Indonesia saat ini tidak lepas dari pengaruh Globalisasi (KBBI V). Globalisasi yang menciptakan negara tanpa batas, pengaruh budaya dan gaya hidup serta hedonisme serta paham globalisme (Deliarnov, 2006: 201). Globalisasi ekonomi menurut Gao Shangquan merujuk pada meningkatnya saling ketergantungan ekonomi akibat semakin berkembangnya perdagangan berbagai komoditas dan jasa yang melewati batas negara, aliran modal internasional, dan semakin cepatnya penyebaran teknologi (Gao Shangquan, 2000: 1). Globalisasi merupakan keterkaitan dan kebergantungan antar bangsa dan manusia di seluruh dunia melalui perdagangan, investasi, perjalanan, budaya populer dan bentuk-bentuk interaksi lain sehingga batas-batas suatu negara menjadi semakin sempit. Patients (consumers) are increasingly interested in being more involved in decisions about their health and increasingly search for online health information (Nananda, 2014)

Globalisasi menjadikan aspek kehidupan global dimana link menjadi tanpa batas, salah salah satu dampak globalisasi 
adalah budaya dan gaya hidup / life style, di antaranya adalah merawat diri baik untuk perempuan maupun laki-laki, dan hal ini disambut baik dan dibaca oleh pemilik modal untuk memanfaatkan kecenderungan merawat diri ini dengan membuka klinik kecantikan (R Went, 1997: 35-59). Beberapa tahun terakhir ini di Indonesia semakin maraknya berbagai macam klinik kecantikan diantaranya adalah Klinik kecantikan estetika Dr. Affandi, Natasha Skin Centre, London Beauty Centre, Erha, dan Larissa yang menjanjikan produk perawatan kecantikan yang mampu menarik hati konsumen. Klinik Kecantikan adalah satu sarana pelayanan kesehatan rawat jalan yang menyediakan jasa pelayanan medik (konsultasi, pemeriksaan, pengobatan dan tindakan medik) untuk mengatasi berbagai kondisi/penyakit yang terkait dengan kecantikan (estetika penampilan) seseorang, yang dilakukan oleh tenaga medik (dokter, dokter gigi, dokter spesialis dan dokter gigi spesialis) sesuai keahlian dan kewenangannya (Direktorat Jenderal Bina Pelayanan Medik. Departemen Kesehatan Republik Indonesia, Pedoman Penyelenggaraan Klinik kecantikan estetika Indonesia, (Departemen Kesehatan, Jakarta, 2007).

The global skincare market is divided into facial care (2/3 of the total sales), hand and body care and sun care. The success of this segment is a prerequisite for the prosperity of the whole beauty industry. Although the economic downturn reduced the growth rate here, it was possible to restore its prerecession growth in subsequent years. A particularity of the Asian skincare markets is the leading role of face-whitening products, as pale skin continues to be considered the beauty ideal in Asia. Because of that there has always been strong demand for skin whiteners (Lopaciuk A, Łoboda M. Global Beauty Industry Trends in the 21st Century. Knowl Manag Innov Knowl Learn [Internet]. 2013;1079-87. Available from:
http://www.toknowpress.net/ISBN/978-9616914-02-4/papers/ML13-365.pdf).

Pertumbuhan binsis kecantikan ini didasari oleh keinginan wanita dan laki-laki metroseksual di Indonesia untuk tampil sempurna sehingga demi mewujudkannya mereka rela membelanjakan uang demi membeli produk perawatan wajah dan tubuh yang harganya mahal. Keinginan untuk tampil cantik/menawan dan terawat merupakan kebutuhan lahiriah seorang manusia khususnya wanita. Bahkan perkembangan jaman yang ada tak lagi berkata demikian, karena kini para pria juga seakan tak mau ketinggalan tampil rapi dan mempesona, golongan pria yang seperti ini dinamakan pria metroseksual (KBBI V). Kenyataan inilah yang mendorong berbagai perusahaan yang bergerak di bidang Beauty And Personal Care untuk terus berinovasi menciptakan produk berkualitas yang dicari konsumen untuk dapat memenangkan pasar.

Pada tahun 2009, bisnis klinik kecantikan nasional mencatatkan kinerja yang cukup tinggi, baik dari segi omzet, ekspor, maupun penyerapan tenaga kerja. Omzet pada tahun 2011 mencapai Rp. 10,4 triliun atau tumbuh $16,9 \%$ di bandingkan dengan 2010 sebesar Rp. 8,9 triliun. Menurut analisis Spire Research And Consulting, dalam beberapa tahun terakhir ini, di Indonesia semakin marak munculnya beragam merek produk kecantikan, terutama produk perawatan kulit dan perawatan tubuh (http://sdhklinik.com/pertumbuhan-bisnisklinik-kecantikan/ . diakses 16 Juni 2017).

Tren bisnis klinik kecantikan berkembang pesat di berbagai belahan dunia, termasuk Indonesia. Negara Indonesia secara umum diakui sebagai salah satu wilayah yang mengalami pertumbuhan paling cepat secara global untuk kategori pasar cosmetics and toiletries. Bisnis klinik kecantikan di Indonesia sangat luas dan menjanjikan, dengan pertumbuhan pangsa pasar yang juga sangat menjanjikan dan menurut survey diperkirakan naik sekitar $10-17 \%$ per tahun 
(http://sdhklinik.com/bisnis-klinikkecantikan/ . diakses 16 Juni 2017).

Perkembangan industri kecantikan sekarang ini sangat pesat. Negara negara maju dan berkembang pun mengikuti perkembangan bisnis industri kecantikan yang sangat menjanjikan bagi perusahaan. Indonesia pun tak mau kalah. Perkembangan industri di Indonesia sangat berkembang dengan baik, bahkan Indonesia adalah salah satu negara potensi besar dalam industri kecantikan yang pertumbuhannya hingga tahun 2016 diperkirakan 20\% (http://www.ekbis.sindonews.com, 2015. Diakses 16 Juni 2017).

Klinik kecantikan seharusnya mengutamakan kualitas perawatan yang telah teruji klinis dari pada mengutamakan profit tetapi pasien tidak mendapatkan hasil yang maksimal. Ini menyebabkan kebutuhan perlindungan konsumen semakin perlu diperhatikan, agar pemilik bisnis dan pelakunya tidak hanya memperdulikan profit oriented saja. Apabila tidak segera dilakukan dilakukan perancangan kontruksi model perlindungan hukum pengguna Klinik kecantikan estetika dalam perspektif perlindungan hak konstitusional warga negara yaitu hak kesehatan dan hak perlindungan konsumen, maka akan menimbulkan masalah yang berlarut-larut sehingga membesar.

Konsekuensi Indonesia sebagai penganut konstitusionalisme adalah pemenuhan hak konstitusional, globalisasi mempengaruhi pemenuhan hak tersebut, semakin banyak perkembangan maka semakin banyak juga tuntutan akan pemenuhan hak. Pengguna klinik kecantikan estetika merupakan pihak yang harus dilindungi hak konstitusionalnya disebut sebagai pasien atau konsumen kesehatan, karena mendapatkan pelayanan kesehatan dan produk dan jasa di klinik tersebut. Berdasarkan Black's Law Dictionary,

Consumer is a person who buys goods or service for personal, family, or household use, wihy no intention or resale; a natural person who use product for personal rather than bussines purpose (Bryan. A.Garner, 60).

Sedangkan dalam Text book on consumer Law, "consumer is one who purchase goods or service"(David Oughton and John Lowry, 1997:1-2). Definisi tersebut menghendaki bahwa konsumen adalah setiap orang atau individu yang harus dilindungi selama tidak memiliki kapasitas dan bertindak sebagai produsen, pelaku usaha dan atau pebisnis.

Namun dibalik pesatnya pertumbuhan klinik kecantikan ternyata terdapat sisi negatifnya, di antaranya adalah di saat konsumen telah terlanjur membayar mahal terhadap layanan produk dan jasa kecantikan yang telah dibelinya, namun ketika mengalami komplikasi dalam pemakaiannya yang malah semakin memperburuk kondisi kulit konsumen. Di antara kasus yang pernah terjadi akibat klinik kecantikan adalah meninggalnya mahasiswi yang bernama Hilda Pasman, pada 7 Agustus 2004, di sebuah klinik kecantikan di daerah Kebon Jeruk, Jakarta Barat

(https://beautywithoutsurgery.wordpress.co $\mathrm{m} / 2009 / 03 / 19 /$ belajar-dari-kasus-hilda/.

diakses 30 november 2015). Korban meninggal dunia dikarenakan dilakukan tindakan suntik silikon kepada tubuhnya dalam kondisi korban sedang sakit demam tinggi. Sehingga korban kejang dan akhirnya meninggal dunia.

Kasus yang lain adalah Di Klinik Marwah Skincare Jalan Pangeran Santri Nomor 60, Jalan Kebon Kol Nomor 52 dan Jalan Terusan 11, Kabupaten Sumedang, Pada 30 November 2015 terjadi tindak pidana memproduksi atau mengedarkan sediaan farmasi yang tidak memiliki ijin edar dan atau melakukan praktek kefarmasiaan tanpa keahlian dan kewenangan, sebagaimana dimaksud pada Pasal 197 jo Pasal 106 ayat (1) dan atau Pasal 198 jo Pasal 108 Undang-undang RI Nomor 36 Tahun 2009 Tentang Kesehatan

143 | Siska Diana Sari, Perlindugan hukum bagi pengguna klinik... 
(http://www.indofakta.com/?read/huk/4515/ bbpom $\sim$ bandung $\sim$ diduga $\sim$ tidak $\sim$ serius $\sim$ tang ani kasus klinik marwah. diakses 30 November 2015). Pelaku telah dipidana dengan pidana penjara selama 15 (lima belas) tahun dan denda sebanyak $\mathrm{Rp}$ 100.000.000,00 (seratus juta rupiah).

Kasus selanjutnya pada 22 November 2012, di klinik Indivara Aesthetic ditemukan adanya penjualan sediaan farmasi berupa kosmetik yang tidak dilengkapi dengan ijin edar dari Balai Pengawas Obat-obatan dan Makanan (BPOM) serta tidak bernotifikasi.

Berdasarkan latar belakang tersebut maka Peneliti tertarik untuk melakukan penelitian dengan judul Perlindungan Hukum Bagi Pengguna Klinik Kecantikan Estetika Dalam Perspektif Hak Konstitusional Warga Negara. Adapun rumusan masalah pada penelitian ini adalah

Bagaimanakah konsep perlindungan hukum bagi pengguna klinik kecantikan estetika dalam perspektif hak konstitusional warga negara?c

\section{METODE}

\section{Jenis Penelitian}

Metode yang digunakan melalui pendekatan empiris normatif yang dianalisis secara kualitatif, Analisis data pada penulisan hukum lazimnya dilakukan melalui pendekatan kualitatif. Menurut Soerjono Soekanto pendekatan kualitatif adalah cara penelitian yang menghasilkan deskriptif analisis yaitu apa yang dinyatakan oleh responden secara tertulis atau lisan dan juga perlakuannya yang nyata diteliti dan dipelajari sebagai suatu kesatuan yang utuh (Soerjono Soekanto, 2006). Metode kualitatif sebagai cara penjabaran data terhadap data-data tersebut berdasakan studi literatur dan hasil temuan di lapangan (empiris). Data yang diperoleh tadi disusun dalam bentuk pengumpulan data, kemudian reduksi data/pengolahan data, kemudian sajian data dan selanjutnya diambil kesimpulan/verifikasinya, dilakukan saling menjalin dengan proses pengumpulan data.

\section{Waktu dan Tempat Penelitian}

Waktu penelitian bulan Desember 2017-Agustus 2018. Penelitian ini dilaksanakan di beberapa tempat seperti (a) Perpustakaan Universitas Sebelas Maret Surakarta (b) Perpustakaan MK (c)Perpustakaan Kementerian Kesehatan (d) Perpustakaan Kementerian Hukum dan HAM (e) 10 Klinik kecantikan estetika di pulau jawa

\section{Target/Subjek Penelitian}

Target/subjek penelitian ini yakni terdiri dari(a) Penyelenggara klinik kecantikan estetika (b) Pengguna klinik kecantikan estetika (c) Dinas kesehatan Kota/Kabupaten (d) BPPT Kota/Kabupaten

\section{Prosedur}

Penelitian ini dilakukan melalui beberapa prosedur yakni dimulai dari mengumpulkan (a) Kajian pustaka (b) Pengumpulan data (c) Analisis Data (d) Penyusunan laporan dan (d) Diseminasi hasil penelitian

\section{Data, Intrumen, dan Teknik Pengumpulan Data}

Untuk penelitian doktrinal data primer yang digunakan dalam penelitian ini adalah peraturan perundang-undangan terkait hukum kesehatan. sedangkan data sekunder meliputi literatur, buku, makalah, data elektronik, laporan penelitian dan sebagainya yang berkaitan dengan kebijakan hukum kesehatana Indonesia yang terkait dengan klinik kecantikan estetika.

Teknik pengumpulan data yang digunakan dalam penelitian ini adalah dengan melakukan penelitian lapangan, yakni teknik pengumpulan data dengan cara peneliti mengadakan pengamatan secara langsung pada sasaran yang diteliti dan melakukan pencatatan secara sistematik 
dengan menggunakan instrumen berupa pedoman observasi.

\section{Teknik Analisis Data}

Berdasarkan keseluruhan data yang terkumpul akan dianalisa dengan model analisis interaktif (interactive model of analysis) dari Miles dan Huberman, menurutterdapat tiga macam kegiatan analisis data kualitatif, yaitu: reduksi data, display data, dan penggambaran kesimpulan. Oleh karena penelitian ini menggabungkan jenis penelitian hukum doktrinal dan non-doktrinal, maka analisisnya dipisahkan. Untuk penelitian hukum doktrinal menggunakan analisis deduktif sedangkan penelitian hukum nondoktrinal menggunakan analisis induktif.

\section{HASIL DAN PEMBAHASAN}

\section{Perlindungan Hukum}

Perlindungan hukum bagi rakyat merupakan konsep universal, dalam arti dianut dan diterapkan oleh setiap negara yang mengedepankan diri sebagai negara hukum, namun seperti disebutkan Paulus E. Lotulung, "masing-masing negara mempunyai cara dan mekanismenya sendiri tentang bagaimana mewujudkan perlindungan hukum tersebut, dan juga sampai seberapa jauh perlindungan hukum itu diberikan" (Paulus E. Lotulung, 1993:123) .

Ada dua macam perlindungan hukum bagi rakyat, yaitu perlindungan hukum preventif dan represif. Pada perlindungan hukum preventif, rakyat diberikan kesempatan untuk mengajukan keberatan (inspraak) atau pendapatnya sebelum suatu keputusan pemerintah mendapat bentuk yang definitif. Artinya perlindungan hukum yang preventif bertujuan untuk mencegah terjadinya sengketa, sedangkan sebaliknya perlindungan yang represif bertujuan untuk menyelesaikan sengketa. Perlindungan hukum yang preventif sangat besar artinya bagi tindakan pemerintahan yang didasarkan kepada kebebasan bertindak, karena dengan adanya perlindungan hukum yang preventif pemerintah terdorong untuk bersikap hatihati dalam mengambil keputusan yang didasarkan pada diskresi.

Mengapa warga negara harus mendapat perlindungan hukum dari tindakan pemerintah? Ada beberapa alasan, yaitu Pertama, karena dalam berbagai hal warga negara dan badan hukum perdata tergantung pada keputusan-keputusan dan ketetapanketetapan pemerintah, seperti kebutuhan terhadap izin yang diperlukan untuk usaha perdagangan, perusahaan atau pertambangan. Oleh karena itu, warga negara dan badan hukum perdata perlu mendapat perlindungan hukum, terutama untuk memperoleh kepastian hukum dan jaminan keamanan, yang merupakan faktor penentu bagi kehidupan dunia usaha. Kedua, hubungan antara pemerintah dengan warga negara tidak berjalan dalam posisi sejajar. Warga negara merupakan pihak yang lebih lemah dibandingkan dengan pemeirntah. Ketiga, berbagai perselisihan warga negara dengan pemerintah itu berkenaan dengan keputusan dan ketetapan, sebagai instrumen pemerintah yang bersifat sepihak dalam melakukan intervensi terhadap kehidupan warga negara. Pembuatan keputusan dan ketetapan yang didasarkan pada kewenangan bebas (vrijebevoegdheid) akan membuka peluang terjadinya pelanggaran hak-hak warga negara. Meskipun demikian, bukan berarti kepada pemerintah tidak diberikan perlindungan hukum. Sebagaimana disebutkan Sjachran Basah, perlindungan hukum terhadap administrasi negara itu sendiri dilakukan terhadap sikap tindaknya dengan baik dan benar menurut hukum (Paulus E. Lotulung, 1993:123)

\section{Klinik kecantikan estetika}

\section{Pengertian Klinik kecantikan estetika}

Pasal 1 Angka 1 Peraturan Menteri Kesehatan Republik Indonesia Nomor 028/Menkes/Per/I/2011 tentang Klinik, menyebutkan bahwa "Klinik adalah fasilitas 
pelayanan kesehatan yang menyelenggarakan pelayanan kesehatan perorangan yang menyediakan pelayanan medis dasar dan/atau spesialistik, diselenggarakan oleh lebih dari satu jenis tenaga kesehatan dan dipimpin oleh seorang tenaga medis ${ }^{1}$ ".

Pasal 2 ayat (1) Peraturan Menteri Kesehatan Republik Indonesia Nomor 028/Menkes/Per/I/2011 tentang Klinik, membedakan klinik menjadi klinik pratama dan klinik utama. Klinik kecantikan estetika adalah satu fasilitas pelayanan kesehatan (praktik dokter perorangan atau berkelompok) yang bersifat rawat jalan dengan menyediakan jasa pelayanan medis seperti konsultasi, pemeriksaan, pengobatan, dan tindakan medis. Untuk mengatasi berbagai kondisi yang terkait kecantikan (estetika penampilan) seseorang yang dilakukan oleh tenaga medis sesuai keahlian dan kewenangannya (Direktorat Jendral Bina Pelayanan Medik Kementerian Kesehatan RI, 2007: 6).

\section{Tipe-Tipe Klinik kecantikan estetika}

Klinik Kecantikan dibagi dalam jenis/katagori dan tipe sebagai berikut :

\section{Klinik Kecantikan}

\section{Kepemilikan Klinik kecantikan estetika}

Penyelenggara (Kepemilikan) Klinik Kecantikan dapat dilakukan secara :

Perorangan dan Badan Hukum. Badan hukum yakni Badan usaha yang sah secara hukum (Perseroan Terbatas, yayasan atau koperasi) Setiap Klinik Kecantikan dan Klinik Kecantikan Spesialis wajib memiliki seorang penganggung jawab teknis medik dengan latar belakang pendidikan minimal dokter (plus). Klinik Kecantikan harus memasang papan nama yang minimal memuat nama, katagori/tipe dan nomor izin klinik kecantikan. Klinik kecantikan wajib membantu program pemerintah di bidang pelayanan kesehatan kepada masyarakat.
Iklan yang dilakukan oleh Klinik Kecantikan tidak boleh bertentangan dengan norma yang berlaku dalam masyarakat serta peraturan perundangan yang berlaku

\section{Hubungan Hukum Antara Klinik kecantikan estetika Dan Pengguna}

Hubungan hukum antara klinik kecantikan dan konsumen tercipta karena adanya perikatan.

Perjanjian yang tidak memenuhi syarat-syarat tersebut tidak akan diakui oleh hukum, walaupun diakui oleh para pihak yang membuatnya. Ilmu hukum mengenal dua jenis perjanjian, yaitu:

\section{1) Resultaatsverbintenis}

Perjanjian yang berdasarkan hasil kerja, artinya suatu perjanjian yang akan memberikan resultaat atau hasil yang nyata sesuai dengan apa yang diperjanjikan.

2) Inspanningsverbintenis

Perjanjian yang berdasarkan usaha yang maksimal (perjanjian upaya, artinya kedua belah pihak berjanji atau sepakat untuk berdaya upaya secara maksimal untuk mewujudkan apa yang diperjanjikan) .

Berdasarkan dua jenis perjanjian di atas, maka pada dasarnya perjanjian sebagai dasar hubungan hukum antara konsumen dan dokter di klinik kecantikan adalah perjanjian terapeutik. Perjanjian terapeutik yaitu sebuah perjanjian antara dokter dan pasien dimana masing-masing harus memenuhi syarat-syarat dalam aturan hukum. Perjanjian terapeutik dapat dikategorikan sebagai perjanjian inspanningsverbintenis, dimana klinik kecantikan sebagai fasilitas pelayanan kesehatan dibidang kecantikan dituntut untuk berusaha maksimal dan sungguhsungguh dalam melakukan penyembuhan dengan didasarkan pada standa ilmu pengetahuan kedokteran yang baik.

Konsumen klinik kecantikan merupakan pihak yang meminta pertolongan sehingga relatif lemah kedudukannya dibandingkan dengan dokter sebagai penyelenggara klinik 
kecantikan. Untuk mengurangi kelemahan tersebut, maka dikenal prinsip informed consent, yaitu hak konsumen untuk mengizinkan dilakukannya suatu tindakan medis. informed consent diatur dalam Peraturan Menteri Kesehatan Republik Indonesia Nomor 585/ Men.Kes/Per/IX/1989 tentang Persetujuan Tindakan Medis. Persetujuan tindakan medis ( informed consent) dalam ketentuan ini adalah persetujuan yang diberikan oleh konsumen jasa pelayanan kesehatan atau keluarganya atas dasar penjelesan mengenai tindakan medis yang akan dilakukan terhadap konsumen .Tujuan dari informed consent adalah agar konsumen mendapat informasi yang cukup untuk mengambil keputusan atas terapi yang akan dilaksanakan. Pada dasarnya perjanjian terapeutik harus didahului dengan informed consent. Sedangkan Produk pada klinik jasa kecantikan ini terdiri dari jasa, obat dan berupa kosmetik.

\section{Hak Konstitusional Warga Negara}

Hak konstitusional warga negara adalah hak-hak yang bersangkutan dengan konstitusi negara (KBBI V:2018). Hak konstitusional warga negara yang meliputi hak asasi manusia dan hak warga negara yang dijamin dalam UUD 1945

Pengguna klinik kecantikan estetika merupakan pihak yang harus dilindungi hak konstitusionalnya disebut sebagai pasien atau konsumen kesehatan, karena mendapatkan pelayanan kesehatan dan produk dan jasa di klinik tersebut.

\section{Perlindungan Hukum Bagi Pengguna Klinik Kecantikan Estetika Dalam Perspektif Hak Konstitusional Warga Negara}

Hak konstitusional warga
negara harus di jamin dalam
konstitusi sebagai bentuk pengakuan
HAM serta adanya peradilan yang independen tidak terpengaruh oleh penguasa dan segala tindakan pemerintahan harus didasarkan atas hukum. Terkait dengan praktek kkinik kecantikan estetik, perlindungan hukum, pelaksanaan dan penegakan hak konstitusional warga negara yang harus dipenuhi oleh negara dan klinik kecantikan yaitu hak jaminan perlindungan dan kepastian hukum dan hak kesehatan serta berhak memperoleh pelayanan kesehatan. Hak-hak dan kebebasan tersebut ada yang tercantum dalam UUD 1945 dan ada pula yang tercantum hanya dalam undang-undang tetap memiliki kualitas yang sama pentingnya secara konstitusional sehingga dapat disebut memiliki "constitutional importance" yang sama dengan yang disebut eksplisit dalam UUD 1945 [11]. Sesuai dengan prinsip social contract, maka setiap hak yang terkait dengan warga negara dengan sendiri bertimbal-balik dengan kewajiban negara untuk memenuhinya. Demikian pula dengan kewenangan konstitusional yang dimiliki oleh negara melalui organorgannya juga bertimbal-balik dengan kewajiban konstitusional yang wajib ditaati dan dipenuhi oleh setiap warga negara.

Perlindungan dan penegakan hak konstitusional merupakan kewajiban semua pihak. Hak konstitusional tidak hanya mencakup mengenai hak, tetapi terkait pula mengenai kewajiban, yaitu kewajiban untuk saling menghormati dan menghargai hak konstitusional orang lain. Sehingga terdapat pembatasan dan larangan dalam pelaksanaan perlindungan hak asasi konstitusional Pembatasan yang ditetapkan melalui undang-undang dimaksudkan untuk menjamin pengakuan dan penghormatan atas hak dan kebebasan orang lain, dan untuk memenuhi tuntutan. 
Perlindungan hukum pengguna pengguna klinik kecantikan estetika dalam perspektif perlindungan hak konstitusional warga negara adalah sebagai upaya perlindungan warga negara sebagai pasien dan konsumen dipandang secara materiil maupun formil semakin terasa penting, mengingat ilmu pengetahuan dan teknologi yang merupakan penggerak bagi produktifitas dan efisiensi produsen atas barang atau jasa yang dihasilkan dalam rangka mengejar dan mencapai kedua hal tersebut, akhirnya baik langsung maupun tidak langsung, maka konsumen akan merasakan dampaknya (Edmon Makarim, 2003: 327).

Sudah sejak lama perlindungan hukum bagi konsumen hanya didasarkan pada doktrin caveat emptor, yaitu suatu paham tentang perlunya konsumen untuk senantiasa berhati-hati, karena pelaku usaha tidak diwajibkan untuk menunjukkan cacat, kecuali jika diminta dan harus menyatakannya. Setiap transaksi yang terjadi merupakan hasil kesepakatan antara pihak pelaku usaha dan pembeli (konsumen). Pelaku usaha menyerahkan barang dan konsumen membayar harga. Konsumen menanggung atas risikonya sendiri terhadap suatu barang setelah kewajiban pokok masing-masing pihak telah terpenuhi secara timbal balik.

Banyaknya kerugian yang dialami pengguna atas pelayanan klinik kecantikan yang tengah menjamur ini mengharuskan pemerintah untuk segera melakukan perancangan konstruksi model perlindungan hukum pengguna klinik kecantikan estetika dalam perspektif perlindungan hak konstitusional warga negara. Adanya BPSK (Badan Penyelesaian Sengketa Konsumen) sebagai perintah UndangUndang belum bisa efektif menjangkau masalah perlindungan kosumen klinik kecantikan. Keberadaan BPSK yang terbatas dan tidak selalu ada di setiap Kota/Kabupaten dan pendanaannya dibebankan kepada APBD (Anggaran Pendapatan dan Belanja Daerah) menyebabkan cukup beratnya pemerintah daerah untuk mendukung eksistensi dan efektifitas BPSK. Sebagian besar konsumen yang dirugikan akan meninggalkan pelayanan di klinik kecantikan, sedikit yang berani menuntut dan mendatangi langsung untuk meminta kerugian pada klinik kecantikannya. Data yang diperoleh dari website Mahkamah tidak cukup banyak putusan pengadilan yang terkait klinik kecantikan, hanya berkisar 40-an (empat puluhan) saja (https://putusan.mahkamahagung.go.id/m ain/pencarian/?q=klinik+kecantikan,

diakses tanggal 2 Februrari 2018). Masalah yang dialami pengguna klinik kecantikan ini seperti gunung es, tidak muncul dipermukaan, tetapi aslinya sangat besar.

Perlindungan pengguna klinik kecantikan ini menjadi sangat penting karena penyelenggaraan klinik kecantikan seharusnya sesusai dengan pedoman tentang penyelenggaraan kinik kecantikan estetik di Indonesia, akan tetapi kondisi yang terjadi sekarang terkait perlindungan hukum pengguna pengguna klinik kecantikan estetika dalam perspektif perlindungan hak konstitusional warga negara adalah pelayanan di klinik kecantikan yang meliputi:

1. Tenaga medis yang berwenang

2. Jenis pelayanan/tindakan medis

3. Alat yang digunakan

4. Penggunaan tenaga nuklir, bahan kimia, Obat-obatan dan produk kosmetik

5. Legalitas lembaga pelatihan klinik kecantikan

6. Perijinan dan pengawasan operasional klinik kecantikan 
7. Tanggungjawab klinik kecantikan apabila ada kondisi yang tidak sesuai yang diharapakan.

Kondisi tersebut menyebabkan semakin mendesaknya kebutuhan terhadap perlindungan hukum pengguna pengguna klinik kecantikan estetika, karena semakin banyaknya bisnis klinik kecantikan. Kebutuhan perlindungan konsumen atas jasa pelayanan kesehatan klinik kecantikan estetis berkaitan dengan pemenuhan hak-hak konstitusional, yaitu hak kesehatan dan hak perlindungan konsumen. Sekalipun kebutuhan akan klinik kecantikan ini termasuk kebutuhan kesehatan tersier, akan tetapi saat ini sangat berkembang pesat dan kebutuhan akan klinik kecantikan ini sangat meningkat. Pemerintah seharusnya melihat ini sebagai suatu prospek bisnis yang baik tetapi juga peringatan untuk lebih meningkatkan proteksi terhadap konsumen, terutama di saat terjadinya kerugian/ kejadian yang tidak diharakan konsumen ketika dana tau setelah mendapatkan pelayanan di klinik kecantikan.

Sebagaimana kita ketahui dari kota besar sampai kota kecil saat ini banyak sekali klinik-klinik kecantikan. Hal ini harus diimbangi dengan jaminan perlindungan hukum terhadap pengguna klinik kecantikan tersebut. Konsumen dalam perspektif ini adalah warganegara, yang secara normatif memperoleh perlindungan hak-hak konstitusional menurut UUD 1945. Diantara hak-hak konstitusional yang paling relevan adalah ketentuan Pasal $28 \mathrm{H}$ ayat (1) yang mengatur bahwa "Setiap orang berhak hidup sejahtera lahir dan batin, bertempat tinggal, dan mendapatkan lingkungan hidup yang baik dan sehat serta berhak memperoleh pelayanan kesehatan." Ketentuan Undang-Undang kemudian menegaskan bahwa setiap individu, keluarga dan masyarakat berhak memperoleh perlindungan terhadap kesehatannya, dan negara bertanggung jawab mengatur agar terpenuhi hak hidup sehat bagi penduduknya (UU No. 36 Tahun 2009 tentang Kesehatan). Dalam konteks ini, hak atas kesehatan mempunyai ruang lingkup yang lebih luas, ia tidak hanya menyangkut hak atas individu saja, tetapi meliputi semua faktor yang memberi konstribusi terhadap hidup yang sehat (healthy self) terhadap individu, seperti masalah lingkungan, nutrisi, perumahan dan lainlain. Sementara hak atas kesehatan dan hak atas pelayanan kedokteran yang merupakan hak-hak pasien, adalah bagian yang lebih spesifik dari hak atas kesehatan .

Konstitusionalitas hak kesehatan dapat pula dikaitkan dengan pemahaman bahwa kesehatan masyarakat adalah pilar pembangunan suatu bangsa. Kesehatan adalah salah satu kebutuhan dasar manusia. Begitu pentingnya, sehingga sering dikatakan bahwa kesehatan adalah segala-galanya, tanpa kesehatan segalagalanya tidak bermakna (Fheriyal Sri Isriawaty, 2015:3)

Perlindungan pengguna klinik kecantikan estetika menjadi penting Karena semakin banyak dan berkembangnya bisnis klinik kecantikan, dan banyak timbulnya masalah dan kasus terkait penyelenggaraannya, akibat dari pelaksanaan tindakan yang tidak sesuai peraturan-perundang-undangan yang terkait. Hal ini menimbulkan kebutuhan perlindungan terhadap resiko kesehatan yang ditimbulkan dari kerugian atas pelayanan di klinik kecantikan yang tidak sesuai dengan peraturan perundangundangan di bidang hukum kesehatan dan hukum perlindungan konsumen. Negara menjadi wajib memberikan perlindungan terkait pelaksanaan hak konstitusional atas perlindungan hukum dan hak atas kesehatan, agar pelaku bisnis klinik kecantikan mentaati segala 
aturan yang berlaku yang terkait dengan pelaksanaannya, meningkatkan tanggungjawab sebagai pelaku usaha terhadap konsumennya.

$$
\text { Penyelenggaraan }
$$

klinik kecantikan estetika idealnya berdasarkan peraturan perundang-undangan yang berlaku. Negara harus dapat memberikan kepastian dan perlindungan hukum kepada pengguna klinik kecantikan estetika dengan pengaturan dan kelembagaan yang baik.

Roscoe Pound's opinion "law is the tool of social engineering" provides the basis, that is, the law is used as a means of social change, the law must play an active role in engineering social change in society, so the law must be a driving force in the direction of social change to be better than Before. The Developmental Law Theory developed by Muchtar Kusumaatmaja based on the Roscoe Pound theory provides the basis for the functioning of the law as a "Community Renewal Tool" (Janssens $\mathrm{H}$, Vanderschueren DMOI. Endocrinological aspects of aging in men: is hormone replacement of benefit? Eur J Obstet Gynecol Reprod Biol. 2000).

Klinik kecantikan estetika idealnya memberikan pelayanan dan produk kosmetik yang aman bagi pengguna, sesuai dengan pedoman penyelenggaraan klinik kecantikan estetika di Indonesia dan Regulation (EC) No 1223/2009 Of The European Parliament And Of The Council of 30 November 2009 on cosmetic products, Article 9:

Cosmetic products should be safe under normal or reasonably foreseeable conditions of use. In particular, a riskbenefit reasoning should not justify a risk to human health (Regulation (EC) No $1223 / 2009$ Of The European
Parliament And Of The Council of 30 November 2009 on cosmetic products: 1).

Regulasi tentang klinik kecantikan secara khusus sudah diatur dalam Pedoman Penyelenggaraan Klinik kecantikan estetika dari Kementerian Kesehatan Republik Indonesia, dan secara umum ada peraturan lain yang terkait dengan hukum kesehatan dan perlindungan konsumen. Penyelenggaraan klinik kecantikan di Indonesia diliputi kedua hukum tersebut.

Pengaturan klinik kecantikan dalam hukum kesehatan yaitu UndangUndang Nomor 29 Tahun 2004 tentang Praktik Kedokteran (kewenangan dokter yang berpraktrek), Pedoman Penyelenggaraan Klinik kecantikan estetika dari Kementerian Kesehatan Republik Indonesia Tahun 2007, Undang-Undang Nomor 36 Tahun 2009 tentang Kesehatan (tanggungjawab pemerintah atas pemenuhan hak sehat), Peraturan Pemerintah Nomor 32 Tahun 1996 tentang Tenaga Kesehatan (terkait tenaga pelaksana yang berwenang, beautician, perawat, apoteker), Peraturan Presiden Nomor 72 Tahun 2012 tentang Sistem Kesehatan Nasional (dasar-dasar pembangunan kesehatan nasional), Peraturan Menteri Kesehatan Nomor 363/Menkes/Per/IV/1998 tentang Pengujian dan Kalibrasi Alat Kesehatan Pada Sarana Pelayanan Kesehatan, Peraturan Menteri Kesehatan Nomor 269/Menkes/Per/III/2008 tentang Rekam Medis (pencatatan riwayat pengguna klinik), Peraturan Menteri Kesehatan Nomor 290/Menkes/Per/III/2008 tentang Persetujuan Tindakan Kedokteran (diperlukan apabila ada tindakan medis beresiko tinggi dan invasive), Peraturan Menteri Kesehatan Nomor 411/Menkes/Per/III/2010 tentang Laboratorium Klinik, Peraturan Menteri Kesehatan Nomor 001 Tahun 2012 tentang Sistem Rujukan Pelayanan 
Kesehatan Perorangan (apabila ada komplikasi atau keadaan kulit yang memburuk), Peraturan Menteri Kesehatan Nomor 36 Tahun 2012 tentang Rahasia Kedokteran, Peraturan Menteri Kesehatan Nomor 46 Tahun 2013 tentang Registrasi Tenaga Kesehatan, Peraturan Menteri Kesehatan Nomor 9 Tahun 2014 Tentang Klinik, Peraturan daerah provinsi dan kota / kabupaten terkait perijinan dan operasional klinik kecantikan

Pengaturan terkait dengan klinik kecantikan di dalam hukum perlindungan konsumen diantaranya Undang-Undang Nomor 8 Tahun 1999 tentang perlindungan konsumen, Peraturan Pemerintah Republik Indonesia. Nomor 57 Tahun 2001 tentang Badan Perlindungan Konsumen Nasional, Peraturan Presiden Nomor 80/2017 Tentang Badan Pengawas Obat dan Makanan Peraturan Menteri Kesehatan Nomor 1176/MENKES/PER/VIII/2010 tentang Notifikasi Produk, Peraturan Pemerintah Republik Indonesia Nomor 58 Tahun 2001 tentang Pembinaan dan Pengawasan Penyelenggaraan Perlindungan Konsumen dan Peraturan Pemerintah Republik Indonesia Nomor 59 Tahun 2001 tentang Lembaga Perlindungan Konsumen Swadaya Masyarakat.

Hasil penelitian, tanggungjawab pemenuhan hak konstitusional yang meliputi praktik klinik kecantikan estetika dan itu jatuh pada pemerintah selaku pembuat aturan sekaligus mengurusi penyelenggaraan klinik kecantikan estetika dan tanggungjawab yang paling inti terdapat pada pihak klinik kecantikan estetika yang melakukan praktik dan pelayanan. Berdasarkan pedoman penyelenggaraan klinik kecantikan estetika yang diterbitkan oleh Direktorat Jenderal Klinik kecantikan estetika, tanggungjawab pemerintah terhadap praktik klinik kecantikan estetika terletak pada perinjinan, pembinaan, pengawasan, monitoring dan evaluasi pelaksanaan penyelenggaraan klinik kecantikan agar menjamin pelayanan yang baik.

Bentuk tanggungjawab pemerintah lainnya ada pada Kementrian Perindustrian dan Perdagangan terkait produksi obat dan kosmetik serta alat yang digunakan, Badan Pengawas Tenaga Nuklir (Bapeten) terkait adanya penggunaan tenaga nuklir yang digunakan, Badan Pengawas Obat dan Makanan (BPOM) terkait peredaran obat dan kosmetiknya, Majelis Ulama Indonesia (MUI) terkait status halal obat dan zat yang digunakan, Badan Perlindungan Konsumen Nasional (BPKN) terkait perlindungan konsumen, Badan Peradilan umum dan Badan Penyelesaian Sengketa Konsumen (BPSK) untuk penyelesaian sengketanya, dan Badan Pelayan Perijinan Terpadu Satu Pintu (BPTSP) untuk perijinan dan Dinas Kesehatan untuk pengawasan dan pembinaan di tingkat kota / kabupaten.

Berdasarkan Undang-Undang Perlindungan Konsumen, Pasal 19-21 tanggungjawab pelaku usaha klinik kecantikan terdiri dari tanggungjawab klinik kecantikan estetika yang pertama adalah tanggungjawab berdasarkan kesalahan, apabila terjadi kesalahan prosedur dalam diagnose, tindakan dan obat yang diberikan, maka pelaku usaha klinik kecantikan harus bertanggungjawab atas kerugian yang dialami konsumen, yang kedua tanggungjawab resiko atas tindakan yang akan dilakukan, misalkan tindakan yang akan menimbulkan efek samping seperti laser atau tindakan media operatif lainnya, yang ketiga tanggung jawab produk yaitu obat dan zat yang didapatkan selama perwatan di klinik kecantikan dan yang keempat adalah tanggungjawab professional yang berarti 
adanya tenaga kesehatan yang berwenang yang dapat melakukan tindakan di klinik kecantikan estetika.

Hasil penelitian menunjukkan hamper seluruh klinik kecantikan estetika yang diteliti memper]kerjakan tenaga pelaksana pelayanan mediknya adalah dokter yang tidak mempunyai kompetensi untuk tindakan medik tertentu (tindakan spesialistik), jenis pelayanan di klinik kecantikan yaitu suntikan dan infus pemutih, perawatan dan pengobatan acne, pelangsingan dan pembentukan tubuh (body slimming / firming), chemical peeling, microdermabrasi, jet peel, cauter, terapi oksigen, mesoterapi, LAT, jenis peralatan di klinik kecantikan yaitu alat slimming, cauter, mikrodermabrator, Laser, IPL dan alat kecantikan berteknologi mutakhir, homogenitas zat kimia yang dicampurkan dalam krim/obat, mayoritas memakai merkuri dan hidroqiunon sebagai pencerah kulit instan, rekam medik dan informed consent yang tidak tertib, instansi Pemerintah yang memberikan ijin opersional klinik kecantikan tidak sinkron dengan daerah lain. Kondisi ini tentu merugikan konsumen, misalnya bahaya merkuri:

Mercury is a metal that is a liquid at room temperature. Mercury has a long and interesting history deriving from its use in medicine and industry, with the resultant toxicity produced. In high enough doses, all forms of mercury can produce toxicity. The most devastating tragedies related to mercury toxicity in recent history include Minamata Bay and Niagata, Japan in the 1950s, and Iraq in the 1970s. More recent mercury toxicity issues include the extreme toxicity of the dimethylmercury compound noted in 1998, the possible toxicity related to dental amalgams, and the disproved relationship between vaccines and autism related to the presence of the mercury- containing preservative, thimerosal (John 2007:237)

\section{SIMPULAN DAN SARAN}

\section{Simpulan}

Perlindungan hukum pengguna klinik kecantikan estetika berdasarkan perspektif hak konstitusional warga negara meliputi tanggung jawab negara dan penyelenggara klinik kecatikan estetika. Adapun hak konstitusional yang harus dilindungi adalah hak mendapatkan pekayanan kesehatan, dan jaminan perlindungan hukum apabila terjadi keadaan yang tidak sesuai dengan harapan pengguna.

\section{Saran}

\section{Pemerintah}

Segera melakukan peninjauan kembali terkait dasar hukum penyelenggaraan klinik kecantikan estetika di daerah, karena pedoman penyelenggaraan yang ada hanya berupa pedoman, yang tingkat kualitas produk hukumnya tidak memiliki kekuatan hukum yang kuat.

Perlu ditingkatkan lagi menjadi produk perundang-undangan yang lebih tinggi lagi, minimal Peraturan Menteri. Selain itu juga konsideran di dalam pedoman tersebut sebagian besar telah dirubah sehingga tidak relevan lagi untuk diberlakukan saat ini.

Perlunya edukasi kosmetik aman dan sehat kepada masyarakat di daerah agar meningkatkan pengetahuan tentang produk dan pelayanan klinik kecantikan estetika.

\section{Pemerintah Daerah}

BPPT agar lebih ketat dalam memberikan ijin penyelenggaraan klinik kecantikan estetika. Dinas Kesehatan melakukan pengawasan dan kontrol secara rutin dan berkala sesuai peraturan perundang-undnagan yang berlaku.

\section{Penyelenggara klinik kecantikan estetika}

Hendaknya lebih mentaati peraturan perundang-undangan yang terkait hukum kesehatan dan perlindungan konsumen yang terkait penyelenggaraan klinik kecantikan estetika.

\section{Masyarakat}


Harus mau mempelajari dahulu tentang pelayanan klinik kecantikan yang baik dan aman agar meminimalisir kerugian yang tidak diharapkan ketika, ataupun setelah perawatan.

\section{DAFTAR PUSTAKA}

Bryan. A.Garner. Black Law Dictionary. London: Linguaphone Institute Limited.

David Oughton and John Lowry. (1997). Textbook an Consumer Law. London: Blackstone Press Limited.

Deliarnov. (2006). Ekonomi Politik. Jakarta: Erlangga.

Direktorat Jenderal Bina Pelayanan Medik. Departemen Kesehatan Republik Indonesia. (2007). Pedoman Penyelenggaraan Klinik kecantikan estetika Indonesia. Jakarta: Departemen Kesehatan.

Edmon Makarim. (2003). Kompilasi Hukum Telematika. Jakarta: PT RajaGrafindo Persada.

Fheriyal Sri Isriawaty, "Tanggung Jawab Negara Dalam Pemenuhan Hak Atas Kesehatan Masyarakat Berdasarkan Undang Undang Dasar Negara Republik Indonesia Tahun 1945", Jurnal Ilmu Hukum Legal Opinion Edisi 2, Volume 3, Tahun 2015

Gao Shangquan. (2000). Economic Globalization: Trends, Risks and Risk Prevention, Economic and Social Affairs, CDP Background Paper No. 1, ST/ESA/2000/CDP/1,

http://sdhklinik.com/bisnis-klinikkecantikan/ . diakses 16 Juni 2017

http://sdhklinik.com/pertumbuhan-bisnisklinik-kecantikan/ . diakses 16 Juni 2017 http://www.ekbis.sindonews.com, 2015. Diakses 16 Juni 2017

http://www.indofakta.com/?read/huk/4515/b bpom bandung diduga tidak seriu s tangani kasus klinik marwah. diakses 30 November 2015.

https://beautywithoutsurgery.wordpress.com /2009/03/19/belajar-dari-kasushildal. diakses 30 november 2015.

https://kbbi.kemdikbud.go.id/entri/metrosek sual . Diakses 16 Juni 2017

https://putusan.mahkamahagung.go.id/main/ pencarian/?q=klinik+kecantikan

Indra Perwira, "Kesehatan Sebagai Hak Asasi Manusia", dalam Bagir Manan, et.al., Dimensi-Dimensi Hukum Hak Asasi Manusia, PSKN FH UNPAD, Bandung, 2009., hlm. 138.

Janssens H, Vanderschueren DMOI. (2000). Endocrinological aspects of aging in men: is hormone replacement of benefit? Eur J Obstet Gynecol Reprod Biol.

Jimly Asshiddiqie. (2005). Konstitusi And Konstitusionalisme Indonesia, Edisi Revisi. Jakarta: Konstitusi Press.

Kamus Besar Bahasa Indonesia. (2014). Jakarta:PT Gramedia

Łopaciuk A, Łoboda M. Global Beauty Industry Trends in the 21st Century. Knowl Manag Innov Knowl Learn [Internet]. 2013;1079-87. Available from:

http://www.toknowpress.net/ISBN/9 78-961-6914-02-4/papers/ML13365.pdf

Mercury Exposure and Public Health. Jack C. Clifton II, MD, MS Email the author MD, MS Jack C. Clifton. Great Lakes Center for Children's Environmental Health, John H. Stroger, Jr. Hospital of Cook County, Chicago, IL, USA. April 
Citizenship Jurnal Pancasila dan Kewarganegaraan Vol 6 No 2 Oktober 2018, hal hal hal 140-154 Avaliable online at : http://e-journal.unipma.ac.id/index.php/Citizenship

Print ISSN: 2302-433X Online ISSN : 2579-5740

2007Volume 54, Issue 2, Pages 237.e1-237.e45. journal Pediatric Clinics of North America

Nananda Col Rosaly Correa-de-Araujo. (2014). Consumers and Clinical Decision Support, Clinical Decision Support (Second Edition). The Road to Broad Adoption.

Paulus E. Lotulung. (1993). Beberapa Sistem tentang Kontrol Segi Hukum terhadap Pemerintah. Bandung: Citra Aditya Bakti.
Peraturan Menteri Kesehatan Republik Indonesia tentang Klinik.

R Went. (1997). "Globalization: Myths, Reality And Ideology: The Eu In A Globalized World". 26(3) Int'1 J. Political Economy.

UU No. 36 Tahun 2009 tentang Kesehatan.

UUD 1945 